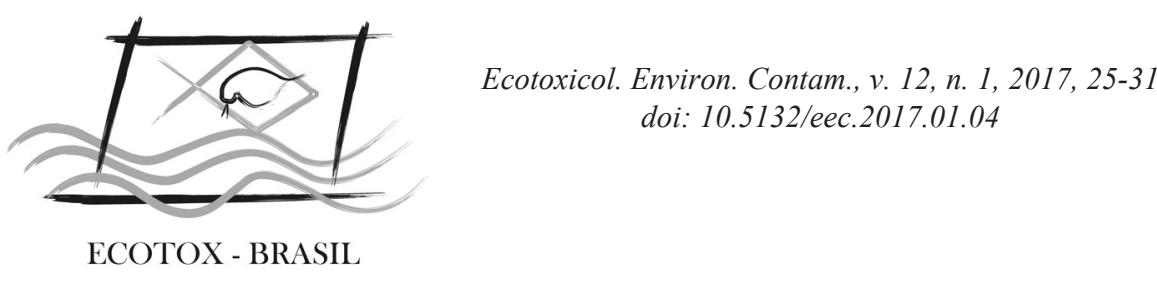

$\underline{\underline{\mathrm{EEC}}}$

\title{
Toxicity assessment of silica nanoparticles on Allium cepa
}

\author{
Silva, G.H. \& Monteiro, R.T.R. \\ Centro de Energia Nuclear na Agricultura, University of São Paulo, C.P. 96, CEP: 13400-970 Piracicaba, Brazil
}

(Received October 31, 2016; Accept March 08, 2017)

\begin{abstract}
Nanotechnology is rapidly expanding, and several new nanoparticle products with improved performance have been developed. The environmental fate and toxicity of nanoparticles (NP) is poorly understood and should be studied to enable the safe use of this technology. This study aims to investigate genotoxic and phytotoxic impacts of silica nanoparticles (SiNP) using root tip cells of Allium cepa as an indicator system. A. cepa root tip cells were exposed to different concentrations (1.82 to $0.54 \mathrm{~g} \mathrm{~L}^{-1}$; dilution factor of 1.5x) of three engineered dispersions of SiNP (TM40 - $22 \mathrm{~nm}$; HS30 - $12 \mathrm{~nm}$; SM30 - $7 \mathrm{~nm}$ ). The following endpoints were measured: mitotic index, different types of chromosomal aberrations, germination index and root length. A decrease in the mitotic index was observed with increasing NP concentration, and significant decreases in the MI for all tested NP were found. For all NP cytological effects including chromosomal aberrations were observed in treated cells. Phytotoxic effects were also observed as germination rate and root growth were significantly reduced $(p<0.05)$. Plants are an essential component of ecosystems and these findings suggest that they should be included when evaluating the toxicological impact of $\mathrm{NP}$ on the environment.
\end{abstract}

Keywords: Nanomaterial. Genotoxicity. DNA damage. Size influence. Aggregation.

\section{INTRODUCTION}

Nanotechnology has been growing exponentially and there have been studies in all areas, including the physical, chemical, environmental and medical fields. Despite the wide range of research about nanoparticles (NP) and nanotechnology there are few studies on the effects of these nanomaterials on health and especially on environmental impacts. Silica nanoparticles (SiNP) are extensively used in manufactured products, for example in additives to drugs, in the chemical industry, in printer toners, in cosmetics and in food (Gordon et al., 2009; Van Hoecke et al., 2011; Fede et al., 2012; IzakNau et al., 2014; Pisani et al., 2015). Nanoparticle materials that are between 1 and 100 nanometres are usually more toxic than bulk materials of larger size (Sager et al., 2008; Kim et al., 2012). Their adverse effects depend on a large number of factors, such as their size, shape, surface/volume ratio, stability, chemical composition, and others, which may be influenced by several environmental parameters (MaurerJones et al., 2013).

*Corresponding author: Helena G. Silva; e-mail: gaby_helena@hotmail.com
Regarding the genotoxicity and cytotoxicity of SiNP most studies have found negative results using several cell lines, and the comet assay (Gehrke et al., 2013; Gonzalez et al., 2014; Tavares et al., 2014). Also, some authors have found chromosomal damage in mouse and human cells (Sergent et al., 2012; Lankoff et al., 2013). As these studies have produced conflicting results, more research is needed to elucidate why and how these particles interact with cells and organisms. It is expected that smaller NP exert higher toxicity, because they may cross biological barriers more easily than larger NP. Some of the controversial results may therefore be explained by differences in nanoparticle size. In addition, nanoparticles are extremely reactive so different types of media and reagents may interact with them and consequently produce different results, making it difficult to compare studies. Not all studies support a relationship between size and nanoparticle toxicity theory. For example, Greish et al. (2012) observed that larger SiNP induced higher toxicity in CD-1 mice than their smaller counterparts. Nevertheless, Park et al. (2013) reported that negatively surface charged $20 \mathrm{~nm}$ SiNP exhibited higher toxicity than the equivalent $100 \mathrm{~nm}$ SiNP in keratinocytes. 
Deeper understanding of the influence of size on SiNP ecotoxicological potential is essential and further research is needed. Furthermore, the effects of SiNP have been studied on human cells, algae, and fish (Van Hoecke et al., 2008; Fent et al., 2010; Fede et al., 2012; Gonzalez et al., 2014; Silva, 2015) but data on the potential toxicity of NP in terrestrial ecological test species is still limited and only a few plants have been used as indicator organisms. Therefore, this work aimed to assess whether SiNP influence the cytotoxicity, genotoxicity and phytotoxicity in Allium cepa.

The Allium cepa root chromosomal aberration assay is a reliable tool for the prediction of the environmental impact of disposed chemicals and nanomaterials. It has been validated by the International Programme on Chemical Safety (IPCS, WHO) and by the United Nations Environmental Programme (UNEP) as an efficient and standard test for the chemical screening and in situ monitoring for the genotoxicity of environmental substances (Cabrera \& Rodriguez, 1999). In addition, Allium cepa is a sensitive, abundant species, with a large geographical distribution and wide availability making it suitable for the evaluation of nanoparticle toxicity (Pakrashi et al., 2014). Many studies have shown important correlations between tests with plants and mammals (Fachinetto et al., 2007; Ray et al., 2013). Rank \& Nielsen (1994) observed a correlation of $82 \%$ between Allium cepa tests and carcinogenicity tests on rats. These findings strengthen the assumption that tests with plants can be robust and expose the dangerous effects that chemicals such as NP can have, not just on the environment but also on human health.

\section{MATERIALS AND METHODS}

\section{Characterisation of nanoparticle suspensions}

For this study, silica nanoparticles were purchased from Sigma-Aldrich (St Louis, USA), as aqueous suspensions with a concentration of $400 \mathrm{~g} \mathrm{~L}^{-1}$ for TM40 and $300 \mathrm{~g} \mathrm{~L}^{-1}$ for HS30 and SM30. They were electrostatically stabilised with negative charges, with sodium as counterion and were of different sizes: TM40 (size: $22 \mathrm{~nm}$ and surface area: 140 $\mathrm{m}^{2} \mathrm{~g}^{-1}$ ), HS30 (size: $12 \mathrm{~nm}$ and surface area: $220 \mathrm{~m}^{2} \mathrm{~g}^{-1}$ ) and SM30 (size: $7 \mathrm{~nm}$ and surface area: $320-400 \mathrm{~m}^{2} \mathrm{~g}^{-1}$ ). In order to obtain a serial dilution to which the seeds of Allium cepa were exposed, the stock solution was diluted with distilled water.

To characterise the NP suspensions a series of physical characterisation experiments were carried out (at the concentration of $0.01 \mathrm{~g} \mathrm{~L}^{-1}$ of SiNPs). In order to measure the hydrodynamic diameter of the particles in suspension (NP size), the aggregation index and the polydispersity index (PDI), dynamic light scattering (DLS) was used. To measure the zeta potential (measure of charge) electrophoretic light scattering (ELS) was performed (Sayes \& Warheit, 2009; Card \& Magnuson, 2010). Information about the stability and size variability of the NP in the medium used for all tests was provided by the zeta potential and polydispersity index. To categorize NP suspensions, the ASTM D4187-82 method (1985), to classify the stability behaviour of particles (i.e. classifying the zeta potential as a high or low value), was used. A Malvern Instrument Zetasizer Nano-ZS instrument (Malvern Instruments Ltd, Worcestershire, UK) was used to measure the parameters mentioned above at $20{ }^{\circ} \mathrm{C}$, in backward scattering at $173^{\circ}$.

\section{Allium cepa assay}

The $A$. cepa assay was performed according to a modified version of Grant's protocol (Grant, 1982). All assays were carried out with only one kind of seed of $A$. cepa (variety Baia Periforme), to avoid different responses in the several stages of the process.

The $A$. cepa seeds were continuously exposed to different concentrations of SiNP: 1.82 to $0.54 \mathrm{~g} \mathrm{~L}^{-1}$ with a dilution factor of $1.5 \mathrm{x}$. These concentrations were selected in order to obtain a stress concentration so that we were able to observe effects and correlate them with the influence of size on geno-, cyto- and phytotoxicity. The tests were conducted at $20 \pm 5^{\circ} \mathrm{C}$ and 12:12 $\mathrm{h}$ light/dark, in covered Petri dishes containing filter paper soaked with the NP solution. Four replicates per treatment, each with 100 seeds were used. A control using distilled water as a negative control was also used (Leme \& MarinMorales, 2008). The seeds were exposed to NP suspensions until the roots in the negative control reached a length of two centimetres (96 hours). At this stage, the germination index, in percentage, was calculated as the proportion of the seeds with visible radicle protrusion. Afterwards 30 randomly selected roots were picked from each replicate of each treatment, measured, collected (only those longer than two centimetres) and fixed in Carnoy 3:1 (ethanol: acetic acid, v/v) for 6-12 h. They were then transferred to a new Carnoy's fixative and stored at $4{ }^{\circ} \mathrm{C}$ before further analysis.

Slide preparation with the meristematic root cells followed the procedure described by Leme \& Marin-Morales (2008). Fixed roots were washed with distilled water and hydrolysed in $1 \mathrm{~N} \mathrm{HCl}$ in a $60{ }^{\circ} \mathrm{C}$ bath for $8-11 \mathrm{~min}$. They were then washed in distilled water again and stained with Schiff's reagent for two hours in the dark, before washing one more time with distilled water. For slide preparation, the meristematic regions were cut onto the slide into a drop of $2 \%$ acetic carmine solution, to increase the cytoplasm contrast, and covered with a cover slip and carefully squashed. Afterwards the cover slip was removed with liquid nitrogen and the slides were mounted in synthetic resin (Enthellan, Merck) for further analysis. In order to evaluate cell damage, ten slides per treatment were prepared and 500 intact cells were analysed per slide, under an optical microscope (1000x), totalling 5000 cells per test for each treatment.

Genotoxic potential was determined for all treatments according to the observation and quantification of any chromosomal and nuclear abnormalities in the meristematic cells, in all phases of the cell cycle, such as abnormal 
telophases and anaphases (e.g. multipolar, with bridges, delayed), fragmented or lost chromosomes, or C-metaphases. Chromosomal aberrations index (CA) was calculated as the ratio between the number of the cells with chromosomal aberration and the total number of cells scored and expressed as percentage. The evaluation of mutagenic effects was carried out by scoring micronucleated cells of meristematic regions in all slides of all treatments. The micronuclei index (MN) was scored as the ratio between the number of micronucleated cells and the total number of cells scored and expressed as percentage. We also analysed the mitotic index (MI) i.e. the number of cells in division. The MI was calculated as the ratio between the number of mitotic cells and the total number of cells scored and expressed as percentage.

\section{DATA ANALYSIS}

All data were analysed using statistical analysis One Way ANOVA (Dunnett test) to determine treatment effects, and then to compare each treatment to the control using the software SAS 9.1 for Windows. All statistical analyses were based on a 0.05 significance level.

\section{RESULTS}

\section{Characterisation of silica nanoparticles}

Through characterisation of the nanoparticles we could evaluate the stability, agglomeration, size and heterogeneity of all SiNP in the distilled water used for the dilutions. Zeta potential and polydispersity index provided information about stability, agglomeration and size heterogeneity of NP in the medium used for all assays. Polydispersity values equal to or lower than 0.2 indicate adequate uniformity of size distribution (Kovacevic et al., 2011), and zeta potential values higher than $-30 \mathrm{mV}$ indicate adequate stability. All of the NP were influenced by the medium used (Table 1). The stability as measured by the zeta potential and polydispersity index was different for each type of particle. TM40 NP were more stable, presenting the lowest polydispersity index (0.122), and the highest zeta potential (-25.99). The polydispersity index for HS30 was 0.251 and its zeta potential was -0.38 ; for SM30 the values were 0.262 and -1.65 , respectively. SM30 particles showed the largest change compared to the primary size reported by Sigma-Aldrich, their diameter changing from $7 \mathrm{~nm}$ to $17.1 \mathrm{~nm}$. For the TM40 NP the average size increased from $22 \mathrm{~nm}$ to $37.2 \mathrm{~nm}$ when diluted, and for HS30 the average size increased from $12 \mathrm{~nm}$ to $19.1 \mathrm{~nm}$.

\section{Allium cepa assay}

The results of the tests with SiNP showed that the percentage of mitotic cells (prophase, metaphase, anaphase and telophase) decreased when exposed to SiNP, however these results were not dose dependent. Also, the results shown an increase of micronucleus, for all nanoparticles, when compared to the control, but the number of micronucleus did not pass $10 \%$ in any of the treatments, therefore, there was no toxicity relevance. The same was observed for chromosomal aberration (Fig. 1).

Phytotoxic effects of SiNP in A. cepa were also observed. The germination rate of the seeds exposed to the studied NPs and the results for the root length after exposure to the NP are shown in Fig. 2. Compared to control, the germination rate presented significantly reduced values $(p<0.05)$ for all particles and for all concentrations, except for TM40 and SM30 at $1.2 \mathrm{~g} \mathrm{~L}^{-1}$. The germination results seem to be dose dependent for HS30, but not for TM40 or SM30. Root length was significantly reduced for NP treatments.

\section{DISCUSSION}

Some studies have investigated the genotoxic and cytotoxic effects of differently sized SiNP at several concentrations and on different organisms, with both positive and negative results (Kim et al., 2012; Liang et al., 2014; Kasper et al., 2015). Conflicting results have also been recorded for phytotoxic effects on different plants (Nair et al., 2011; Slomberg \& Schoenfisch, 2012; Suriyaprabha et al., 2012). In the present study, high doses of SiNP induced cytotoxic but not genotoxic effects in meristematic cells of $A$. cepa. The cytotoxicity was verified by the decreased of the mitotic index. The cytotoxicity level of a test compound can be determined based on the increase or decrease in the mitotic index (MI), which can be used as a parameter of cytotoxicity in studies of environmental biomonitoring (Fernandes et al., 2007). Reduction in cell activity could be due to changes in the mitotic cycle duration, which can be attributed to the increase in $\mathrm{S}$ phase duration (Kumari et al., 2011). Therefore, the SiNP may have a mitodepressive effect on the $A$. cepa roots, effect that could interfere with normal mitosis, preventing cells from entering

Table 1 Physical parameters measured at the highest tested concentration of the three SiNP, using dynamic and electrophoretic light scattering.

\begin{tabular}{lccccc}
\hline & SiNP & $\begin{array}{c}\text { Concentration } \\
\left(\mathbf{g ~ L}^{-1}\right)\end{array}$ & $\begin{array}{c}\text { Size } \\
(\mathbf{n m})\end{array}$ & $\begin{array}{c}\text { Polydispersity } \\
\text { index }\end{array}$ & $\begin{array}{c}\text { Zeta Potential } \\
(\mathbf{m V})\end{array}$ \\
\hline $\mathrm{H}_{2} \mathrm{O}$ dest. & $\mathrm{TM} 40(22 \mathrm{~nm})$ & 0.01 & 37.20 & 0.12 & -25.99 \\
$\mathrm{H}_{2} \mathrm{O}$ dest & $\mathrm{HS} 30(12 \mathrm{~nm})$ & 0.01 & 19.10 & 0.25 & -0.38 \\
$\mathrm{H}_{2} \mathrm{O}$ dest & $\mathrm{SM} 30(7 \mathrm{~nm})$ & 0.01 & 17.10 & 0.26 & -1.65 \\
\hline
\end{tabular}



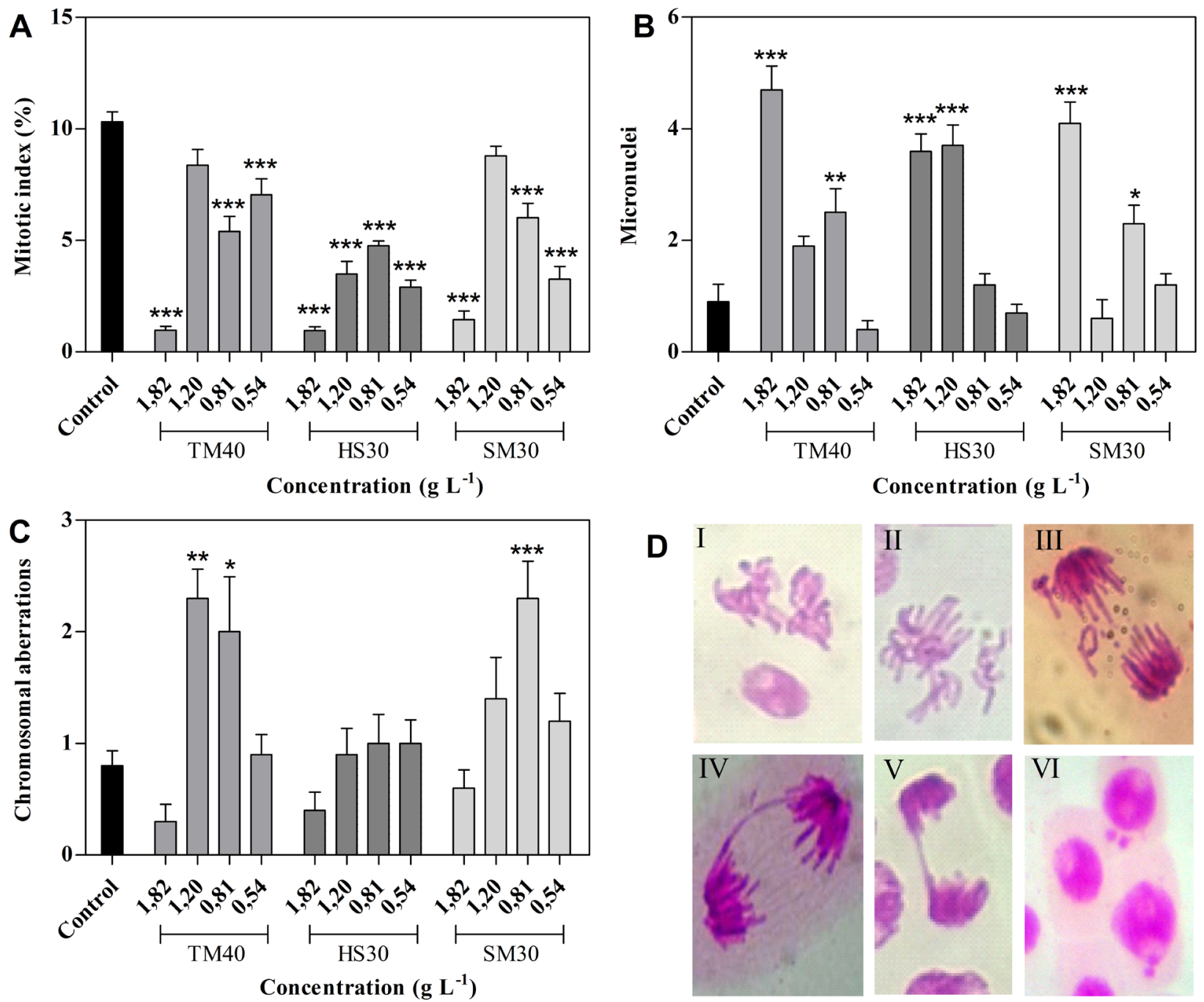

Fig. 1 Silica nanoparticles induced chromosomal aberrations and delays entry into mitosis in root tip cells of $A$. cepa. (A) Graph plotting the mitotic index following treatment of $A$. cepa with SiNP (B) Graph plotting the number of cells presenting micronuclei following treatment of $A$. cepa with $\operatorname{SiNP}(\mathrm{C})$ Graph plotting the number of cells presenting chromosomal aberration following treatment of $A$. cepa with SiNP (D) Representative images of (I) stickiness; (II) disturbed metaphase (III) anaphase with chromosome loss (IV) anaphase with bridge (V) telophase with bridge (VI) micronucleus. Magnification 40x. Asterisks indicate significant differences relative to the negative control $\left({ }^{*} \mathrm{p}<0.05 / * * \mathrm{p}<0.001 / * * * \mathrm{p}<0.0001\right)$

prophase and blocking the mitotic cycle during interphase, thus inhibiting dna/protein synthesis.

Different kinds of chromosomal aberrations were observed, such as chromosomal breaks, bridges, stickiness, and disturbed metaphase. Different chromosomal aberrations in metaphase and anaphase may be caused by the shifting of poles by the depolymerisation of spindle fibbers (Darlington \& McLeish, 1951), also stickiness may cause fragmentation of chromosomes and bridges, leading towards to structural chromosomal mutations (Panda et al., 2011). Toxicity studies carried out by (Yu et al., 2008; Napierska et al., 2009) suggested that amorphous SiNP below $100 \mathrm{~nm}$ induced cytotoxicity, so the size of the particles is critical with respect to their biological effects.

Phytotoxic effects were observed for all SiNP studied, germination rate and root length were significantly reduced. One important parameter, that determines the rate of root growth due cell proliferation, is the mitotic index, which is correlated with the frequency of cell division (d'Aquino et al., 2009). Therefore, the low mitotic index observed in the cytotoxicity assay may have contributed to the short root length observed. Studies with SiNP (of size 14, 50 and $200 \mathrm{~nm}$ ) in A. thaliana found that SiNP can interfere with plant development, and also accumulate in root cells in a size-dependent manner (Slomberg \& Schoenfisch, 2012). Also Stampoulis et al. (2009) studied germination and root growth of $C$. pepo treated with SiNP $(<100 \mathrm{~nm})$. The SiNP completely inhibited germination at $1000 \mathrm{mg} \mathrm{L}^{-1}$ and had a significant impact on root elongation. Those studies present similar results to our experiments on germination and root length in A. cepa exposed to SiNP.

Overall in this study was not observe a dose-dependent toxicity, and only a dependence on size towards to TM40 (being the least toxic, i.e. with bigger size). This may be explained 

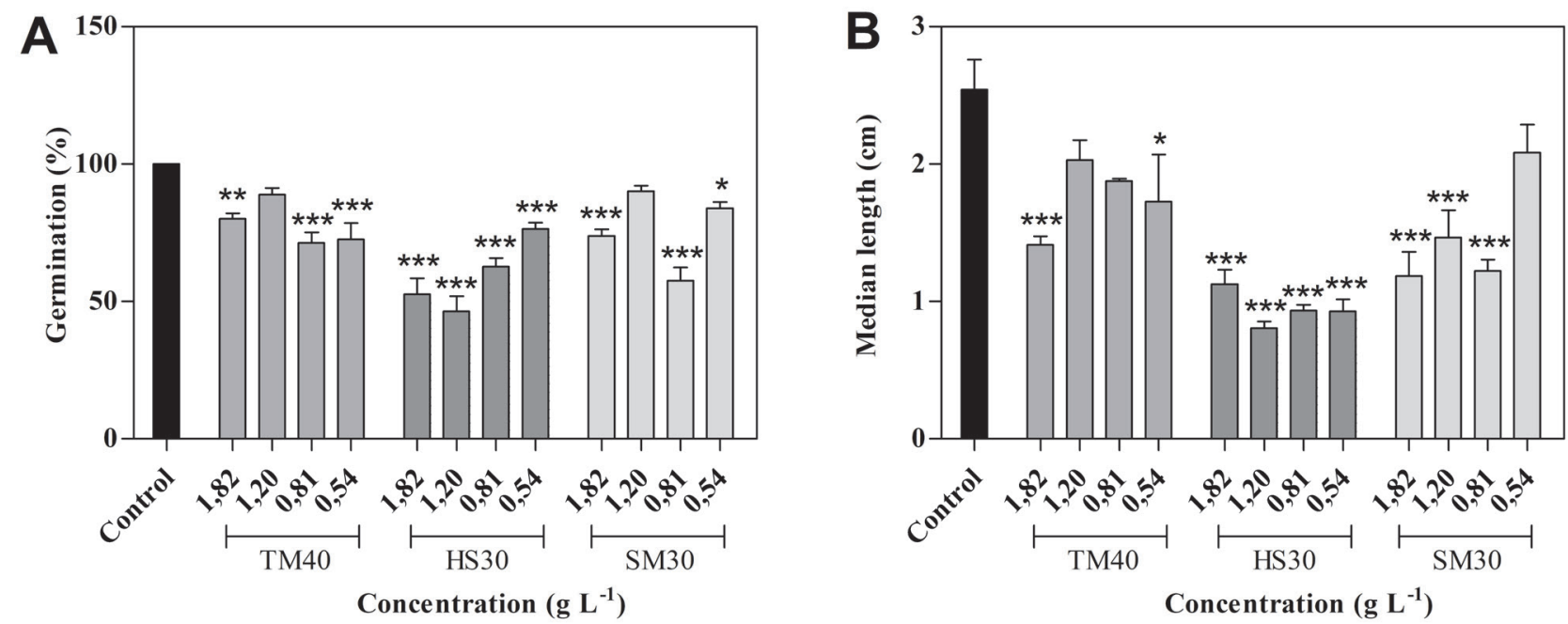

Fig. 2 Silica nanoparticles induced phytotoxicity in Allium cepa. (A) germination rate (ratio between the number of germinated seeds and the total number of seeds scored and expressed as percentage) after exposure to three types of silica nanoparticles at different concentrations. (B) Mean and SD of Allium cepa root length (in $\mathrm{cm}$ ) after exposure to three types of silica nanoparticles at different concentrations. Asterisks indicate significant differences relative to the negative control $(* \mathrm{p}<0.05 / * * \mathrm{p}<0.001 / * * * \mathrm{p}<0.0001)$

by the NP properties, which tend to form agglomerates. Agglomeration would decrease the size differences between the particles, possibly preventing such effect from being observed. This can be confirmed by the DLS results, which shows that the HS30 and SM30 dispersions present a very similar size (19.10 nm and $17.10 \mathrm{~nm}$, respectively), therefore reinforcing the toxicity results. Fang et al. (2015) studied different primary sizes of $\mathrm{TiO}_{2} \mathrm{NP}$ and found a positive correlation between size and surface area or surface energy. Therefore, particles with large surface area or high surface energy usually have a more unstable thermodynamic system, and therefore tend to form aggregates. This may be an explanation for the low stability of the two smaller particles in our research. Also, there are many factors that can influence the aggregation of nanoparticles, including concentration (Narayanan \& El-Sayed, 2005). Therefore, the toxicity results, in our study, may not be dose-dependent due to the fact that the NPs was not stable, thereby it may have a tendency to aggregate more at higher concentrations, causing more effect on toxicity at lower concentrations.

There are still a very limited information concerning the adverse effects of engineered nanomaterials on terrestrial plant systems. Although some studies corroborate our findings, it should be noted that phytotoxicity data for SiNP are still contradictory. While some studies present no phytotoxicity for SiNP, others present negative effects, as presented above, and some even present positive effects of SiNP on plant germination and root length (Nair et al., 2011; Siddiqui et al., 2015). The results presented in this paper provide complementary information regarding the ecotoxicity of SiNP in higher plant systems, and highlight the importance of assessing the nanomaterial properties, such as aggregation, to understand its toxicity and avoid underestimation of their environmental risks.

\section{CONCLUSIONS}

In summary, negative effects were observed after exposure of Allium cepa to high doses of SiNP. Those nanoparticles can penetrate the plant system causing effects on growth, germination and cell division. Our findings provide a complementary information regarding the toxicity of silica nanoparticles to higher plant systems and highlight the importance of the nanoparticles properties to understand their environmental risks. Plants are an important component of ecosystems and these findings suggest that they should be included when evaluating the toxicological impacts of nanoparticles on the environment.

\section{ACKNOWLEDGMENTS}

We would like to thank Dr. Amadeu Soares and Isabel Lopes from the Department of Biology \& CESAM, University of Aveiro, Portugal, also Dr. Filipe Antunes and Dr. Claudia Duarte from the Department of Chemistry, University of Coimbra, Portugal. The authors are grateful to Proof-Reading Services, England.

This study was funded by CNPq and CAPES, Brazil. The author G. Silva acknowledges the support and scholarship provided by SANTANDER, Brazil.

\section{REFERENCES}

CABRERA, G.\& RODRIGUEZ, D.M. 1999. Genotoxicity of soil from farmland irrigated with wastewater using three plant bioassays. Mutat. Res. Mol. Mech. Mutagen., 426(2):211-214. doi:10.1016/S0027-5107(99)00070-6

CARD, J.W. \& MAGNUSON, B.A. 2010. A Method to 
Assess the Quality of Studies That Examine the Toxicity of Engineered Nanomaterials. Int. J. Toxicol., 29(4):402-410. doi:10.1177/1091581810370720

D’AQUINO, L., DE PINTO, M.C., NARDI, L., MORGANA, M., TOMMASI, F. 2009. Effect of some light rare earth elements on seed germination, seedling growth and antioxidant metabolism in Triticum durum. Chemosphere, 75(7):900-905. doi:10.1016/j. chemosphere.2009.01.026

DARLINGTON, C.D. \& MCLEISH, J. 1951. Action of Maleic Hydrazide on the Cell. Nature, 167:773/774. doi: $10.1038 / 167407 \mathrm{a} 0$

FACHINETTO, J.M., BAGATINI, M.D., DURIGON, J., SILVA, A.C.F. DA, TEDESCO, S.B. 2007. Efeito anti-proliferativo das infusões de Achyrocline satureioides DC (Asteraceae) sobre o ciclo celular de Allium cepa. Rev. Bras. Farmacogn., 17(1):49_ 54. doi:10.1590/S0102-695X2007000100011

FANG, T., YU, L.P., ZHANG, W.C., BAO, S.P. 2015. Effects of humic acid and ionic strength on $\mathrm{TiO} 2$ nanoparticles sublethal toxicity to zebrafish. Ecotoxicology 24(10):2054-66. doi:10.1007/s10646-015-1541-6

FEDE, C., SElVestrel, F., COMPAGNIN, C., MOGNATO, M., MANCIN, F., REDDI, E., CELOTTI, L. 2012. The toxicity outcome of silica nanoparticles (Ludox $\AA$ ) is influenced by testing techniques and treatment modalities. Anal. Bioanal. Chem., 404:1789-802. doi:10.1007/s00216-012-6246-6

FENT, K., WEISBROD, C.J., WIRTH-HELLER, A., PIELES, U. 2010. Assessment of uptake and toxicity of fluorescent silica nanoparticles in zebrafish (Danio rerio) early life stages. Aquat. Toxicol., 100(2):218-228. doi:10.1016/j.aquatox.2010.02.019

FERNANDES, T.C.C., MAZZEO, D.E.C., MARIN-MORALES, M.A. 2007. Mechanism of micronuclei formation in polyploidizated cells of Allium cepa exposed to trifluralin herbicide. Pestic. Biochem. Physiol., 88(3):252-259. doi:10.1016/j.pestbp.2006.12.003

GEHRKE, H., FRÜHMESSER, A., PELKA, J., ESSELEN, M., HECHT, L.L., BLANK, H., SCHUCHMANN, H.P., GERTHSEN, D., MARQUARDT, C., DIABATÉ, S., WEISS, C., MARKO, D. 2013. In vitro toxicity of amorphous silica nanoparticles in human colon carcinoma cells. Nanotoxicology, 7(3):274-93. doi:10.3109/17435390.2011.652207

GONZALEZ, L., LUKAMOWICZ-RAJSKA, M., THOMASSEN, L.C.J., KIRSCHHOCK, C.E. A, LEYNS, L., LISON, D., MARTENS, J. A, ELHAJOUJI, A., KIRSCH-VOLDERS, M. 2014. Co-assessment of cell cycle and micronucleus frequencies demonstrates the influence of serum on the in vitro genotoxic response to amorphous monodisperse silica nanoparticles of varying sizes. Nanotoxicology, 8(8):876-84. doi:10.3109/1743 5390.2013 .842266

GORDON, R., LOSIC, D., TIFFANY, M.A., NAGY, S.S., STERRENBURG, F.A.S. 2009. The Glass Menagerie: diatoms for novel applications in nanotechnology. Trends Biotechnol., 27(2):116-27. doi:10.1016/j.tibtech.2008.11.003

GRANT, W.F. 1982. Chromosome aberration assays in allium. Mutat. Res. Genet. Toxicol., 99(3):273-291. doi:10.1016/01651110(82)90046-X

GREISH, K., THIAGARAJAN, G., HERD, H., PRICE, R., BAUER, H., HUBBARD, D., BURCKLE, A., SADEKAR, S., YU, T., ANWAR, A., RAY, A., GHANDEHARI, H. 2012. Size and surface charge significantly influence the toxicity of silica and dendritic nanoparticles. Nanotoxicology, 6(7):713-723. doi:10.3 109/17435390.2011.604442

IZAK-NAU, E., KENESEI, K., MURALI, K., VOETZ, M., EIDEN, S., PUNTES, V.F., DUSCHL, A., MADARÁSZ, E. 2014. Interaction of differently functionalized fluorescent silica nanoparticles with neural stem- and tissue-type cells. Nanotoxicology, 8:138-148. doi:10.3109/17435390.2013.8644 27

KASPER, J.Y., FEIDEN, L., HERMANNS, M.I., BANTZ, C., MASKOS, M., UNGER, R.E., KIRKPATRICK, C.J. 2015. Pulmonary surfactant augments cytotoxicity of silica nanoparticles: Studies on an in vitro air-blood barrier model. Beilstein J. Nanotechnol., 6(1):517-28. doi:10.3762/bjnano.6.54

KIM, T.-H., KIM, M., PARK, H.-S., SHIN, U.S., GONG, M.-S., KIM, H.-W. 2012. Size-dependent cellular toxicity of silver nanoparticles. J. Biomed. Mater. Res. Part A, 100A(4):10331043. doi:10.1002/jbm.a.34053

KOVACEVIC, A., SAVIC, S., VUlETA, G., MÜLlER, R.H., KECK, C.M. 2011. Polyhydroxy surfactants for the formulation of lipid nanoparticles (SLN and NLC): effects on size, physical stability and particle matrix structure. Int. J. Pharm., 406:163-72. doi:10.1016/j.ijpharm.2010.12.036

KUMARI, M., KHAN, S.S., PAKRASHI, S., MUKHERJEE, A., CHANDRASEKARAN, N. 2011. Cytogenetic and genotoxic effects of zinc oxide nanoparticles on root cells of Allium cepa. J. Hazard. Mater., 190:613-21. doi:10.1016/j.jhazmat.2011.03.095

LANKOFF, A., ARABSKI, M., WEGIEREK-CIUK, A., KRUSZEWSKI, M., LISOWSKA, H., BANASIK-NOWAK, A., ROZGA-WIJAS, K., WOJEWODZKA, M., SLOMKOWSKI, S. 2013. Effect of surface modification of silica nanoparticles on toxicity and cellular uptake by human peripheral blood lymphocytes in vitro. Nanotoxicology, 7(3):235-50. doi:10.3109 /17435390.2011.649796

LEME, D.M. \& MARIN-MORALES, M.A. 2008. Chromosome aberration and micronucleus frequencies in Allium cepa cells exposed to petroleum polluted water--a case study. Mutat. Res., 650(1):80-6. doi:10.1016/j.mrgentox.2007.10.006

LIANG, H., JIN, C., TANG, Y., WANG, F., MA, C., YANG, Y. 2014. Cytotoxicity of silica nanoparticles on HaCaT cells. J. Appl. Toxicol., 34(4):367-72. doi:10.1002/jat.2953

MAURER-JONES, M.A., GUNSOLUS, I.L., MURPHY, C.J., HAYNES, C.L. 2013. Toxicity of Engineered Nanoparticles in the Environment. Anal. Chem., 85(19):3036-3049. doi:10.1021/ ac303636s

NAIR, R., POULOSE, A.C., NAGAOKA, Y., YOSHIDA, Y., MAEKAWA, T., KUMAR, D.S. 2011. Uptake of FITC labeled silica nanoparticles and quantum dots by rice seedlings: effects on seed germination and their potential as biolabels for plants. J. Fluoresc., 21(6):2057-68. doi:10.1007/s10895-011-0904-5

NAPIERSKA, D., THOMASSEN, L.C.J., RABOLLI, V., LISON, D., GONZALEZ, L., KIRSCH-VOLDERS, M., MARTENS, J.A., HOET, P.H. 2009. Size-Dependent Cytotoxicity of Monodisperse Silica Nanoparticles in Human Endothelial Cells. Small, 5(7):846-853. doi:10.1002/smll.200800461

NARAYANAN, R. \& EL-SAYED, M.A., 2005. Catalysis with Transition Metal Nanoparticles in Colloidal Solution: Nanoparticle Shape Dependence and Stability. J. Phys. Chem., B 109(26):12663-12676. doi:10.1021/jp051066p

PAKRASHI, S., JAIN, N., DALAI, S., JAYAKUMAR, J., CHANDRASEKARAN, P.T., RAICHUR, A.M., CHANDRASEKARAN, N., MUKHERJEE, A. 2014. In vivo genotoxicity assessment of titanium dioxide nanoparticles by Allium cepa root tip assay at high exposure concentrations. PLoS One, 9(2):e87789. doi:10.1371/journal.pone.0087789

PANDA, K.K., ACHARY, V.M.M., KRISHNAVENI, R., PADHI, B.K., SARANGI, S.N., SAHU, S.N., PANDA, B.B. 2011. In vitro biosynthesis and genotoxicity bioassay of silver nanoparticles using plants. Toxicol. Vitr., 25(5):1097-1105. doi:10.1016/j. tiv.2011.03.008 
PARK, Y.-H., BAE, H.C., JANG, Y., JEONG, S.H., LEE, H.N., RYU, W.-I., YOO, M.G., KIM, Y.-R., KIM, M.-K., LEE, J.K., JEONG, J., SON, S.W. 2013. Effect of the size and surface charge of silica nanoparticles on cutaneous toxicity. Mol. Cell. Toxicol., 9(1):67-74. doi:10.1007/s13273-013-0010-7

PISANI, C., GAILlARD, J.-C., NOUVEL, V., ODORICO, M., ARMENGAUD, J., PRAT, O. 2015. High-throughput, quantitative assessment of the effects of low-dose silica nanoparticles on lung cells: grasping complex toxicity with a great depth of field. BMC Genomics, 16(1):315. doi:10.1186/ s12864-015-1521-5

RANK, J. \& NIELSEN, M.H. 1994. Evaluation of the Allium anaphase-telophase test in relation to genotoxicity screening of industrial wastewater. Mutat. Res. Mutagen. Relat. Subj., 312(1):17-24. doi:10.1016/0165-1161(94)90004-3

RAY,S., KUNDU,L.M., GOSWAMI, S., ROY, G.C., CHATTERJEE, S., DUTTA, S., CHAUDHURI, A., CHAKRABARTI, C.S. 2013. Metaphase arrest and delay in cell cycle kinetics of root apical meristems and mouse bone marrow cells treated with leaf aqueous extract of Clerodendrum viscosum Vent. Cell Prolif., 46(1):109-17. doi:10.1111/cpr.12011

SAGER, T.M., KOMMINENI, C. \& CASTRANOVA, V. 2008. Pulmonary response to intratracheal instillation of ultrafine versus fine titanium dioxide: role of particle surface area. Part. Fibre Toxicol., 5:17. doi:10.1186/1743-8977-5-17

SAYES, C.M. \& WARHEIT, D.B. 2009. Characterization of nanomaterials for toxicity assessment. Wiley Interdiscip. Rev. Nanomedicine Nanobiotechnology, 1(6):660-670. doi:10.1002/ wnan.58

SERGENT, J.A., PAGET, V. \& CHEVILLARD, S. 2012. Toxicity and genotoxicity of Nano-SiO2 on human epithelial intestinal HT-29 cell line. Ann. Occup. Hyg., 56(5):622-630. doi:10.1093/ annhyg/mes005

SIDDIQUI, M.H., AL-WHAIBI, M.H. \& MOHAMMAD, F. (Eds.). 2015. Nanotechnology and Plant Sciences. Springer International Publishing, Cham., 303p. doi:10.1007/978-3-319-14502-0

SILVA, G.H. DA. 2015. Efeitos crônicos das nanopartículas de sílica em Vibrio fischeri, Raphidocelis subcaptata, Danio rerio e Allium cepa. MSc. Dissertation. Universidade de São Paulo/ CENA, Piracicaba, 56p.

SLOMBERG, D.L. \& SCHOENFISCH, M.H. 2012. Silica nanoparticle phytotoxicity to Arabidopsis thaliana. Environ. Sci. Technol., 46(18):10247-54. doi:10.1021/es300949f

STAMPOULIS, D., SINHA, S.K. \& WHITE, J.C. 2009. Assaydependent phytotoxicity of nanoparticles to plants. Environ. Sci. Technol., 43(24):9473-9479. doi:10.1021/es901695c

SURIYAPRABHA, R., KARUNAKARAN, G., YUVAKKUMAR, R., RAJENDRAN, V., KANNAN, N. 2012. Silica Nanoparticles for Increased Silica Availability in Maize (Zea mays. L) Seeds Under Hydroponic Conditions. Curr. Nanosci., 8(6):902-908. doi:10.2174/157341312803989033

TAVARES, A.M., LOURO, H., ANTUNES, S., QUARRÉ, S., SIMAR, S., DE TEMMERMAN, P.-J., VERLEYSEN, E., MAST, J., JENSEN, K.A., NORPPA, H., NESSLANY, F., SILVA, M.J. 2014. Genotoxicity evaluation of nanosized titanium dioxide, synthetic amorphous silica and multi-walled carbon nanotubes in human lymphocytes. Toxicol. In Vitro, 28:60-9. doi:10.1016/j.tiv.2013.06.009

VAN HOECKE, K., DE SCHAMPHELAERE, K.A.C., RAMIREZGARCIA, S., VAN DER MEEREN, P., SMAGGHE, G., JANSSEN, C.R. 2011. Influence of alumina coating on characteristics and effects of $\mathrm{SiO} 2$ nanoparticles in algal growth inhibition assays at various $\mathrm{pH}$ and organic matter contents. Environ. Int., 37(6):1118-1125. doi:10.1016/j. envint.2011.02.009

VAN HOECKE, K., DE SCHAMPHELAERE, K.A.C., VAN DER MEEREN, P., LUCAS, S., JANSSEN, C.R. 2008. Ecotoxicity of silica nanoparticles to the green alga pseudokirchneriella subcapitata: importance of surface area. Environ. Toxicol. Chem., 27(9):1948. doi:10.1897/07-634.1

YU, K.O., GRABINSKI, C.M., SCHRAND, A.M., MURDOCK, R.C., WANG, W., GU, B., SCHLAGER, J.J., HUSSAIN, S.M. 2008. Toxicity of amorphous silica nanoparticles in mouse keratinocytes. J. Nanoparticle Res., 11:15-24. doi:10.1007/ s11051-008-9417-9 